\title{
Hubungan kadar HbA1c dengan profil lipid pada pasien kaki diabetik di RSUP Prof. Dr. R. D. Kandou Manado
}

\author{
${ }^{1}$ Dwi A. Primadana \\ ${ }^{2}$ Karel Pandelaki \\ ${ }^{2}$ M. C. P. Wongkar
}

\author{
${ }^{1}$ Kandidat Skripsi Fakultas Kedokteran Universitas Sam Ratulangi Manado \\ ${ }^{2}$ Bagian Ilmu Penyakit Dalam Fakultas Kedokteran Universitas Sam Ratulangi Manado \\ Email: dwiprimadana@gmail.com
}

\begin{abstract}
Diabetes Mellitus (DM) is a chronic disease due to insufficient insulin production or ineffective usage. Diabetic foot is the most common complication found in DM patients with the rate of cases is still high. DM can be controlled favorably by reaching the expected value of $\mathrm{HbA}_{1 \mathrm{c}}$ and lipid profile. This study aimed to determine the correlation between $\mathrm{HbA}_{1 \mathrm{c}}$ value and lipid profile in diabetic foot patients. This was an analytical descriptive study with a cross-sectional design using secondary data. Samples were 62 diabetic foot patients at Prof. Dr. R. D. Kandou Hospital Manado in the period of January 1 to September 30, 2015. The correlation between $\mathrm{HbA}_{1 \mathrm{c}}$ value and lipid profile was tested by using the Pearson correlation test. The results showed the mean values as follows: $\mathrm{HbA}_{1 \mathrm{c}} 8.5597 \%$; total cholesterol $168.0484 \mathrm{mg} / \mathrm{dL}$; HDL $37.3871 \mathrm{mg} / \mathrm{dL}$; LDL $119.2419 \mathrm{mg} / \mathrm{dL}$; and triglyceride 132.0645 $\mathrm{mg} / \mathrm{dL}$. The Pearson correlation test showed that the correlation between $\mathrm{HbA}_{1 \mathrm{c}}$ and total cholesterol had an $\mathrm{r}=0.096$ and a $\mathrm{p}=0.458$; between $\mathrm{HbA}_{1 \mathrm{c}}$ and $\mathrm{HDL}$ had an $\mathrm{r}=0.056$ and a $\mathrm{p}=0.665$; between $\mathrm{HbA}_{1 \mathrm{c}}$ and LDL had an $\mathrm{r}=0.243$ and a $\mathrm{p}=0.057$; and between $\mathrm{HbA}_{1 \mathrm{c}}$ and triglyceride had an $r=0.014$ and a $p=0.913$. Conclusion: There was a positive but not significant correlation between $\mathrm{HbA}_{1 \mathrm{c}}$ and total cholesterol, HDL, LDL, and triglyceride levels.
\end{abstract}

Keywords: $\mathrm{HbA}_{1 \mathrm{c}}$, lipid profile, diabetic foot

\begin{abstract}
Abstrak:Diabetes Melitus (DM) adalah penyakit kronik yang terjadi akibat terganggunya produksi insulin atau penggunaannya yang tidak efektif dan dapat berlanjut mengalami komplikasi. Kaki diabetes merupakan komplikasi tersering yang ditemukan pada penderita DM dengan angka kejadiannya masih tinggi sampai saat ini. Diabetes dapat terkendali dengan baik bila kadar lipid dan $\mathrm{HbA}_{1 c}$ mencapai target terapi yang diharapkan. Penelitian ini bertujuan untuk mengetahui hubungan antara kadar $\mathrm{HbA}_{1 \mathrm{c}}$ dengan kadar profil lipid pada pasien kaki diabetes. Penelitian ini bersifat deskriptif analitik dengan pendekatan potong lintang menggunakan data sekunder. Jumlah sampel sebanyak 62 pasien yang berobat di RSUP Prof. Dr. R. D. Kandou Manado periode 01 Januari 2015 - 30 September 2015. Hubungan kadar $\mathrm{HbA}_{1 \mathrm{c}}$ dengan kadar profil lipid diuji dengan menggunakan uji korelasi Pearson. Hasil penelitian ini menunjukkan nilai-nilai mean sebagai berikut: $\mathrm{HbA}_{1 \mathrm{c}}$ 8,5597\%; kolesterol total 168,0484 mg/dL; HDL 37,3871 mg/dL; LDL 119,2419 mg/dL; dan trigliserida $132,0645 \mathrm{mg} / \mathrm{dL}$. Uji korelasi Pearson menunjukkan korelasi antara kadar $\mathrm{Hb}_{1 \mathrm{c}}$ dengan kolesterol total $\mathrm{r}=0,096$ dan $\mathrm{p}=0,458$; dengan kadar HDL $\mathrm{r}=0,056$ dan $\mathrm{p}=0,665$; dengan kadar LDL $r=0,243$ dan $p=0,057$; dan dengan kadar Trigliserida $r=0,014$ dan $p=0,913$. Simpulan: Terdapat hubungan positif antara kadar $\mathrm{HbA}_{1 \mathrm{c}}$ dengan kadar kolesterol total, HDL, LDL, dan trigliserida namun secara statistik tidak bermakna.
\end{abstract}

Kata kunci: $\mathrm{HbA}_{1 c}$,profil lipid, kaki diabetes 
Diabetes Melitus (DM) adalah penyakit yang akan diderita seumur hidup. ${ }^{1}$ International Diabetes Federation (IDF) pada tahun 2013 menemukan jumlah penderita DM sebesar 382 juta di dunia dan diperkirakan akan mencapai 592 juta pada tahun 2035. Populasi penderita DM ditemukan 80\% lebih banyak di negara berkembang. Di Amerika jumlah penderita DM 61 juta orang, lebih sedikit dibandingkan Asia Tenggara dengan 72 juta orang. Di Indonesia sendiri ditemukan sebesar 8,5 juta penderita DM dan menjadikannya menduduki peringkat ke tujuh dunia setelah Mexico. ${ }^{2}$ Data Riset Kesehatan Dasar (Riskesdas) tahun 2013 menemukan di Provinsi Sulawesi Utara prevalensi DM untuk penduduk usia $\geq 15$ tahun adalah sebesar 3,6\%. ${ }^{3}$

Penelitian tahun 2013 di United Kingdom (UK) melaporkan 5-7\% penderita diabetes memiliki masalah kaki diabetes. ${ }^{4}$ Kaki diabetes merupakan komplikasi tersering ditemukan pada penderita DM yang angka kejadiannya masih cukup tinggi sampai saat ini. ${ }^{5}$ Di Afrika sebesar 21,53\% penderita DM menjalani perawatan di rumah sakit akibat masalah kaki diabetes, 95\% diantaranya disebabkan masalah neuropati. ${ }^{6}$ Penelitian di Indonesia pada tahun 2013, menunjukkan prevalensi pasien yang menjalani perawatan kaki diabetes adalah sebesar $25 \%$. Walaupun tidak begitu banyak laporan riset terkait luka kaki diabetes di Indonesia. ${ }^{7}$

Kaki diabetes merupakan salah satu komplikasi kronik dari DM. ${ }^{8}$ Komplikasi ini terjadi akibat kerusakan saraf (neuropati) dan pembuuh darah.,8,9 Penyakit pembuluh darah perifer disebabkan oleh keadaan hiperglikemia dan juga oleh faktor lain seperti hiperlipidemia. ${ }^{8}$ Keadaan hiperglikemia ditandai dengan peningkatan glikohemoglobin yang menyebabkan meningkatnya kadar hemoglobin terglikosilasi $\left(\mathrm{HbA}_{1 \mathrm{c}}\right) .{ }^{10}$ Pada pembuluh darah penderita DM berisiko mengalami aterosklerosis dengan penyebab yang multifaktorial. Peningkatan kadar lemak dalam darah diketahui merupakan faktor predisposisi terjadinya atero- sklerosis. Perubahan kualitatif pada lipoprotein juga memengaruhi pengaturan lipid dan mudah mengendap di jaringan. High Density Lipoprotein (HDL) merupakan molekul pelindung ateroskeloris, namun kadarnya ditemukan rendah pada penderita DM. ${ }^{11}$

Dalam upaya pencegahan komplikasi kronik penderita DM, diperlukan pengendalian yang baik. Diabetes dapat terkendali dengan baik bila kadar lipid dan kadar $\mathrm{HbA}_{1 \mathrm{c}}$ mencapai kadar yang diharapkan. ${ }^{1}$ Pengukuran kadar $\mathrm{HbA}_{1 \mathrm{c}}$ dalam darah dianggap penting sebab pemeriksaan ini akan menghasilkan indeks rerata kadar glukosa darah selama usia eritrosit yaitu 120 hari (3 bulan). ${ }^{11}$

Ditemukan jumlah penderita kaki diabetes yang cukup tinggi dan diperkirakan akan terus bertambah seiring tidak terkontrolnya kadar $\mathrm{HbA}_{1 \mathrm{c}}$ dan kadar profil lipid, membuat peneliti tertarik melakukan penelitian yang bertujuan untuk mengetahui hubungan kadar $\mathrm{HbA}_{1 \mathrm{c}}$ dengan kadar profil lipid pada pasien kaki diabetes di RSUP Prof. Dr. R. D. Kandou Manado.

\section{METODE PENELITIAN}

Penelitian ini menggunakan metode deskriptif analitik dengan pendekatan potong lintang. Penelitian ini dilakukan di RSUP Prof. Dr. R. D. Kandou Manado selama bulan Oktober - Desember 2015. Populasi ialah seluruh pasien kaki diabetes yang berobat di RSUP Prof. Dr. R. D. Kandou Manado periode 01 Januari 2015 30 September 2015 berjumlah 512 pasien. Sampel penelitian ialah seluruh pasien kaki diabetes yang memilki data kadar $\mathrm{HbA}_{1 \mathrm{c}}$ dan kadar profil lipid berjumlah 62 pasien.

Penelitian ini menggunakan data sekunder yaitu rekam medik (pasien kaki diabetes yang berobat di RSUP Prof. Dr. R. D. Kandou Manado, baik rawat inap maupun rawat jalan. Data dianalisis menggunakan program SPSS dengan uji korelasi Pearson.

\section{HASIL PENELITIAN}

Pada Tabel di bawah dari 62 data yang ada terdapat 36 orang laki-laki dan 26 
orang perempuan. Untuk usia minimun sampel 41 tahun dan maksimum 80 tahun, dengan rerata 59,35 tahun dan standar deviasi 7,87. Kadar $\mathrm{HbA}_{1 \mathrm{c}}$ minimun 4,50\% dan maksimum $15,00 \%$, dengan rerata 8,55\% dan standar deviasi 2,48. Kadar Kolesterol Total minimum 47,00 mg/dL dan maksimum 313,00 mg/dL, dengan rerata $168,04 \mathrm{mg} / \mathrm{dL}$ dan standar deviasi 68,85 .

Tabel 1. Karakteristik Umum pada Sampel Penelitian

\begin{tabular}{lccccc}
\hline \multicolumn{1}{c}{ Variabel } & $\mathrm{N}$ & Min & Max & Mean & SD \\
\hline $\begin{array}{l}\text { Jenis } \\
\text { Kelamin }\end{array}$ & & & & & \\
$\begin{array}{l}\text { Laki-laki } \\
\text { Perempuan }\end{array}$ & 36 & & & & \\
$\begin{array}{l}\text { Usia (Tahun) } \\
\text { HbA }(\%)\end{array}$ & 62 & 41 & 80 & 59,35 & 7,87 \\
$\begin{array}{l}\text { Profil Lipid: } \\
\text { KT (mg/dL) }\end{array}$ & 62 & 4,50 & 15,00 & 8,55 & 2,48 \\
$\begin{array}{l}\text { HDL } \\
\text { (mg/dL) }\end{array}$ & 62 & 5,00 & 72,00 & 37,38 & 15,15 \\
$\begin{array}{l}\text { LDL } \\
\text { (mg/dL) }\end{array}$ & 62 & 31,00 & 245,00 & 119,24 & 48,15 \\
$\begin{array}{l}\text { Trigliserida } \\
\text { (mg/dL) }\end{array}$ & 62 & 57,00 & 294,00 & 132,06 & 61,85 \\
\hline
\end{tabular}

Kadar HDL minimum 5,00 mg/dL dan maksimum 72,00 mg/dL, dengan rerata 37,38 mg/dL dan standar deviasi 15,15. Kadar LDL minimum 31,00 mg/dL dan maksimum 245,00 mg/dL, dengan rerata $119,24 \mathrm{mg} / \mathrm{dL}$ dan standar deviasi 48,15. Kadar trigliserida minimum 57,00 mg/dL dan maksimum 294,00 mg/dL, dengan rerata $132,06 \mathrm{mg} / \mathrm{dL}$ dan standar deviasi 61,85 .

Untuk mengetahui adanya hubungan antara kadar $\mathrm{HbA}_{1 \mathrm{c}}$ dengan kadar profil lipid, digunakan analisis bivariat yaitu dengan uji korelasi Pearson. Gambar 1 menunjukkan hubungan yang positif antara kadar $\mathrm{HbA}_{1 \mathrm{c}}$ dengan kadar kolesterol total dengan koefisien korelasi 0,096 (sangat lemah). Nilai $\mathrm{p}=0,458$ menunjukkan tidak terdapat hubungan yang bermakna antara kadar $\mathrm{HbA}_{1 \mathrm{c}}$ dengan kadar kolesterol total.

Gambar 2 menunjukkan hubungan positif antara kadar $\mathrm{HbA}_{1 \mathrm{c}}$ dan kadar HDL dengan koefisien korelasi 0,056 (sangat lemah), sedangkan nilai $\mathrm{p}=0,665$ menunjukkan tidak terdapat hubungan bermakna antara kadar $\mathrm{HbA}_{1 \mathrm{c}}$ dan kadar HDL

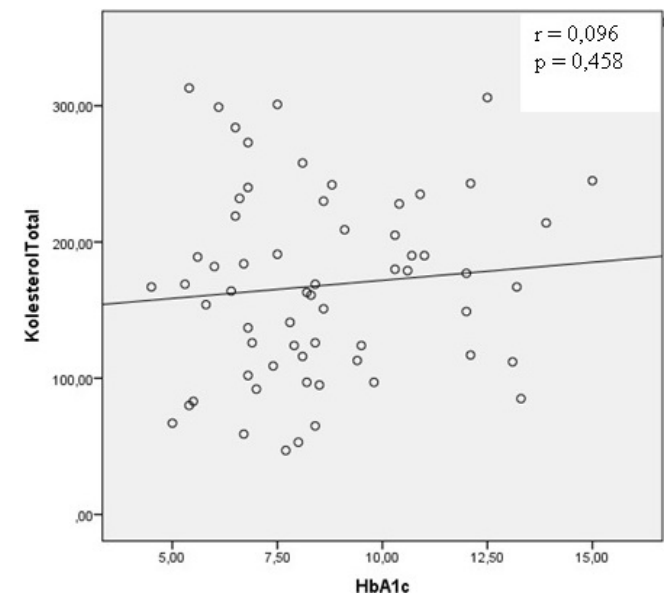

Gambar 1. Hubungan kadar $\mathrm{Hb}_{1 c}$ dengan kadar Kolesterol Total



Gambar 2. Hubungan kadar $\mathrm{HbA}_{1 \mathrm{c}}$ dengan kadar HDL

Gambar 3 menunjukkan terdapat hubungan positif antara kadar $\mathrm{HbA}_{1 \mathrm{c}}$ dan kadar LDL dengan koefisien korelasi adalah 0,243 (lemah), sedangkan nilai $\mathrm{p}=$ 0,057 menunjukkan tidak terdapat hubungan bermakna antara kadar $\mathrm{HbA}_{1 \mathrm{c}}$ dan kadar LDL.

Gambar 4 menunjukkan terdapat hubungan positif antara kadar $\mathrm{HbA}_{1 c}$ dan kadar trigliserida dengan koefisien korelasi 0,014 (sangat lemah), sedangkan nilai $\mathrm{p}=$ 0,913 menunjukkan tidak terdapat hubungan bermakna antara kadar $\mathrm{HbA}_{1 \mathrm{c}}$ dan kadar trigliserida. 


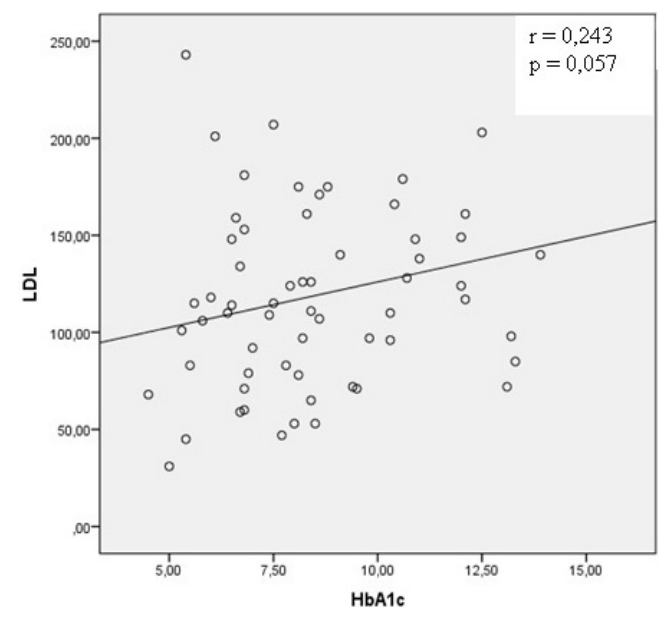

Gambar 3. Hubungan kadar $\mathrm{HbA}_{1 \mathrm{c}}$ dengan kadar LDL

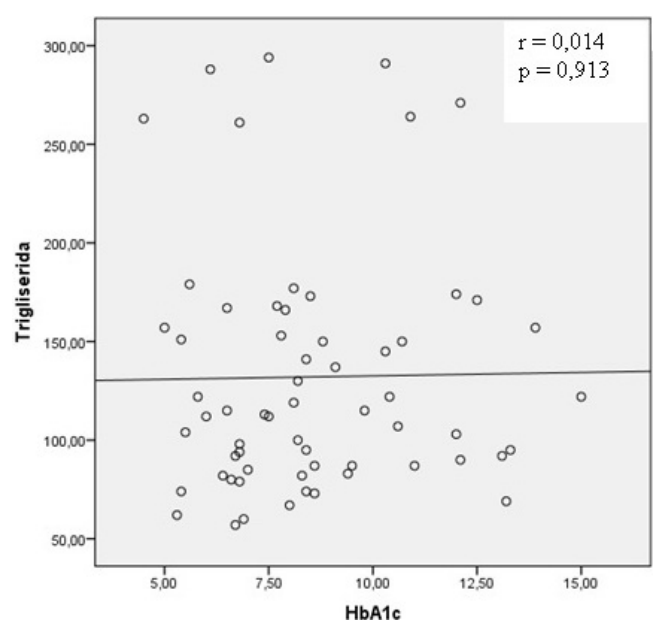

Gambar 4. Hubungan kadar $\mathrm{HbA}_{1 \mathrm{c}}$ dengan kadar Trigliserida

\section{BAHASAN}

Berdasarkan hasil penelitian, gambaran untuk kategori jenis kelamin didapatkan sampel terbanyak ialah laki-laki. Penelitian sebelumnya oleh Al-Rubeaan juga menemukan hasil yang sama yaitu pasien kaki diabetes paling banyak berjenis kelamin laki-laki. ${ }^{12,13}$ Jenis kelamin lakilaki merupakan faktor predominan terjadinya komplikasi kaki diabetes. ${ }^{12}$

Gambaran uji statistik analisis hubungan antara kadar $\mathrm{HbA}_{1 \mathrm{c}}$ dan kadar kolesterol total, terdapat hubungan positif dengan koefisien korelasi 0,096 (sangat lemah) sedangkan nilai $\mathrm{p}=0,458$ menunjukkan tidak terdapat hubungan bermakna antara kadar $\mathrm{HbA}_{1 \mathrm{c}}$ dan kadar kolesterol total. Penelitian yang dilakukan oleh Tamang menemukan hal yang berbeda bahwa terdapat hubungan positif dan bermakna antara kadar $\mathrm{HbA}_{1 \mathrm{c}}$ dan kadar Kolesterol Total. ${ }^{14}$

Uji statistik analisis hubungan antara kadar $\mathrm{HbA}_{1 \mathrm{c}}$ dan kadar HDL mendapatkan hubungan positif dengan koefisien korelasi 0,056 (sangat lemah) sedangkan nilai $\mathrm{p}=$ 0,665 menunjukkan tidak terdapat hubungan bermakna antara kadar $\mathrm{HbA}_{1 \mathrm{c}}$ dan kadar HDL. Hasil yang sangat berbeda ditemukan pada penelitian sebelumnya oleh Khan dimana terdapat hubungan negatif dan bermakna antara kadar $\mathrm{HbA}_{1 \mathrm{c}}$ dan kadar HDL. ${ }^{15}$

Uji statistik analisis hubungan antara kadar $\mathrm{HbA}_{1 \mathrm{c}}$ dan kadar LDL pada penelitian ini mendapatkan hubungan positif dengan koefisien korelasi 0,243 (lemah) sedangkan nilai $\mathrm{p}=0,057$ menunjukkan tidak terdapat hubungan bermakna antara kadar $\mathrm{HbA}_{1 c}$ dan kadar LDL. Hasil yang berbeda ditemukan oleh Singh dimana terdapat hubungan positif dan bermakna antara kadar $\mathrm{HbA}_{1 \mathrm{c}}$ dan kadar LDL. ${ }^{16}$

Uji statistik, analisis hubungan antara kadar $\mathrm{HbA}_{1 \mathrm{c}}$ dan kadar trigliserida, terdapat hubungan positif dengan koefisien korelasi 0,014 (sangat lemah) sedangkan nilai $\mathrm{p}=$ 0,913 menunjukkan tidak terdapat hubungan bermakna antara kadar $\mathrm{HbA}_{1 \mathrm{c}}$ dan kadar trigliserida. Hasil yang berbeda ditemukan oleh Tamang dimana terdapat hubungan positif dan bermakna antara kadar $\mathrm{HbA}_{1 \mathrm{c}}$ dan kadar trigliserida. ${ }^{14}$

Penderita DM dengan komplikasi kaki diabetes akan mengalami keadaan hiperglikemia. Bila hal ini terjadi berkepanjangan, maka akan memengaruhi secara tidak langsung pada profil lipid. ${ }^{17}$ Sebuah penelitian menyatakan bahwa pengukuran kadar $\mathrm{HbA}_{1 \mathrm{c}}$ dapat memrediksi profil lipid pada pasien diabetes. ${ }^{15}$

Sampel dalam penelitian ini ialah pasien kaki diabetes yang telah menjalani perawatan baik di rawat inap dan di Poliklinik Kaki sehingga kebanyakan pasien sudah mendapatkan pengobatan untuk kontrol gula darah dan profil lipid. 
Selain itu faktor usia juga sangat penting dalam memengaruhi kadar profil lipd selain kadar $\mathrm{HbA}_{1 \mathrm{c}}$. Semakin bertambahnya usia maka akan terjadi beberapa perubahan komposisi tubuh seperti peningkatan jumlah jaringan lemak sebesar 30\% dan penurunan sensitivitas reseptor insulin. Selain itu aktivitas fisik yang berkurang, pola makan tinggi karbohidrat, dan perubahan neuro-hormonal pada usia lanjut dapat menimbulkan resitensi insulin. ${ }^{18}$

Resistensi insulin pada obesitas sentral dapat menyebabkan terganggunya proses penyimpanan lemak dan sintesis lemak. ${ }^{19}$ Keadaan ini akan memengaruhi metabolisme lipoprotein dan memicu terjadinya dislipidemia. $^{20}$ Lipolisis trigliserida akan terjadi dan mengakibatkan kadar asam lemak bebas dalam darah meningkat. ${ }^{11}$

Keadaan dislipidemia juga sering menyertai pasien diabetes, ditandai dengan peningkatan kadar trigliserida, dan penurunan kadar kolesterol HDL, sedangkan kadar kolesterol LDL normal atau sedikit meningkat. ${ }^{1}$ Selain itu gangguan kadar lipid dalam darah akan menimbulkan stress oksidatif dimana memicu terbentuknya small dense LDL. ${ }^{21}$

Kadar $\mathrm{HbA}_{1 c}$ yang tinggi dapat terjadi pada beberapa keadaan seperti anemia defisiensi besi, anemia aplastik, kehamilan, uremia, dan konsumsi alkohol berlebihan. ${ }^{22}$ Dalam penelitian ini peneliti kurang membahas komplikasi lain mikrovaskular dan makrovaskular dari penyakit DM, sebab kondisi ini memiliki target kadar $\mathrm{HbA}_{1 \mathrm{c}}$ yang lebih rendah. $^{23}$ Selain itu peneliti tidak mencantumkan data pengobatan yang sedang dijalani pasien seperti pengobatan anti diabetes dan anti kolesterol, sehingga dapat mempengaruhi hasil pemeriksaan dan menyebabkan variasi hasil dalam penelitian.

\section{SIMPULAN}

Terdapat hubungan positif antara kadar $\mathrm{HbA}_{1 \mathrm{c}}$ dengan kadar kolesterol total, HDL, LDL, dan trigliserida.

\section{UCAPAN TERIMA KASIH}

Ucapan terimakasih ditujukan kepada dr. Ventje Kawegian, SpPD atas kritik dan masukannya, Bagian Rekam Medik RSUP Prof. DR. R. D. Kandou Manado yang telah memberikan izin penelitian, serta semua pihak yang terlibat membantu dalam penelitian ini.

\section{DAFTAR PUSTAKA}

1. PERKENI. Konsensus Pengendalian dan Pencegahan Diabetes Melitus Tipe 2 di Indonesia. Jakarta, 2011.

2. International Diabetes Federation (IDF). Diabetes Atlas 2013. International Diabetes Federation (IDF), 2013.

3. RISKESDAS. Jakarta: Litbangkes, 2013.

4. International Best Practice Guildlines: Wounds management in diabetic foot ulcers. Wounds International, 2013.

5. Yazdanpanah L, Nasiri M, Adarvishi S. The management of diabetic foot ulcer. WJD. 2015;6:37-53.

6. Hode AK, Djrolo F, Guenou DA. Epidemiological and clinical features of diabetic foot in Cotonou. Journal of diabetes mellitus. 2015;5:173-80.

7. Yusuf S. Urgensi riset dan pubikasi luka kaki diabetik di Indonesia. Jurnal Luka Indonesia. 2015;1(2):1-2.

8. Waspadji S. Kaki diabetes. Dalam: Sudoyo WA, Setiyohadi B, Alwi I, Simadibrata M, Setiati S. Buku ajar penyakit dalam (5th ed). Jakarta: Interna Publishing; 2009; p. 1961-5.

9. Schteingart DE. Pankreas: metabolisme glukosa dan diabetes mellitus. In: Price SA, Wilson LM. Patofisiologi (6th ed). Jakarta: EGC, 2012; p. 1259-72.

10.Maidina TS, Djallalluddin, Yasmina A. Hubungan kadar $\mathrm{HbA}_{1 \mathrm{c}}$ dengan kejadian kaki diabetik pada pasien diabetes mellitus. Berkala Kedokteran. 2013;9:211-217.

11.Clare MJ, Crawford JM, Kumar V. Pankreas. In: Kumar, Cotran, Robbins. Buku ajar patologi. (7th ed). Jakarta: EGC, 2013; p. 724-31.

12.Roza RL, Afriant R, Edward Z.Faktor risiko terjadinya ulkus diabetikum pada pasien diabetes mellitus yang dirawat jalan dan inap di RSUP Dr. M. Djamil dan RSI Ibnu Sina Padang. Jurnal Kesehatan Andalas. 2015;4(2):243-5. 
13.Al-Rubeaan K, Al Derwish M, Ouizi S, Youssef AM, Subhani SN, Ibrahim HM, et al. Diabetic foot complication and their risk factors from a large retrospective cohort study. Plos One DOI journal. 2015;10:4.

14.Tamang MK, Shakya PR, Dhakal N, Khatiwada S, Lamsal M, Baral N. Correlation of blood glucose level, glycated hemoglobin, total cholesterol and triacylglycerol level in diabetic patients attending tertiary care hospital in eastern Nepal. Global journal of science frontier research. 2014;14:12.

15.Khan HA, Sobki SH, Khan SA. Association between glycaemic control and serum lipids profiles in type 2 diabetic patients: $\mathrm{HbA}_{1 \mathrm{c}}$ predicts dyslipidaemia. Clinical and experimental medicine. 2007;7:24-9.

16.Singh G, Kumar A. Relationship among HbA1c and lipid profile in Punajbi type 2 diabetic population. Journal of exercise science and physiotherapy. 2011;7:99-102.

17.Priyadi R, Saraswati MR. Hubungan antara kendali glikemik dengan profil lipid pada penderita diabetes melitus tipe 2. Universitas Udayana. 2011:1-12.
18. Rochmah W. Diabetes melitus pada usia lanjut. In: Sudoyo AW, Setiyohadi B, Alwi I, Simadibrata M, Setiati S, editors. Buku Ajar Ilmu Penyakit Dalam (5th ed). Jakarta: Interna Publishing, 2009: p. 1969-71.

19.Sugondo S. Obesitas. In: Sudoyo AW, Setiyohadi B, Alwi I, Simadibrata M, Setiati S, editors. Buku Ajar Ilmu Penyakit Dalam (5th ed). Jakarta: Interna Publishing, 2009; p.1973.

20.Adam JMF. Dislipidemia. Dalam: Sudoyo AW, Setiyohadi B, Alwi I, Simadibrata M, Setiati S, editors. Buku Ajar Ilmu Penyakit Dalam (5th ed). Jakarta: Interna Publishing, 2009; p. 1991-2.

21.Shahab A. Komplikasi kronik DM penyakit jantung koroner. In: Sudoyo AW, Setiyohadi B, Alwi I, Simadibrata M, Setiati S, editors. Buku Ajar Ilmu Penyakit Dalam. (5th ed). Jakarta: Interna Publishing, 2009; p. 1939.

22.Paputungan SR, Sanusi H. Peranan pemeriksaan hemoglobin A1c pada pengelolaan diabetes melitus. CDK220. 2014;41:650-5.

23. American Diabetes Association (ADA). Diabetes guidelines summary recommendations. 2015. 